\title{
The Story of a City with Bleak Houses: The Study of the Social Distress in Dickens's Bleak House
}

\section{Fatemeh Pourjafari}

Department of English Language and Literature, Kerman Branch, Islamic Azad University,

\author{
Kerman, Iran
}

\section{Morteza Babaei}

M.A in English Literature

DOI - http://doi.org/10.37502/IJSMR.2021.4801

\begin{abstract}
Bleak House is an especially interesting case among Dickens's novels, in which fact and fiction are integrated proficiently within the context of the novel. The plot is basically made upon imaginative events, while the author's perspective in describing the Victorian London is essentially realistic. This article aims at reading Bleak House as a realistic portrait of the Victorian London, by demonstrating that the moral corruption of the ruling administration, particularly the legal system, is at the root of the general misery and bleakness that prevailed the lives of people. The study indicates how Dickens has tried to express the belief that certain aspects of the real world would become remote to our sensibilities through time, and that it is art's mission to keep them alive.
\end{abstract}

Keywords: Dickens, Bleak House, Social Distress, Art, Reality.

\section{Introduction}

Bleak House is the story of a Victorian waste land called London. It is the city of death and decay, misery and darkness, in which the social institutions move towards the destruction of the individuals rather than bringing life and comfort to them. London is bleak because human values have lost their meanings, and money and social state are criteria to measure individuals' worth. London is sterile.

"Within the course of Dickens's life, Britain transformed itself from a predominantly agricultural nation into the acknowledged industrial leader of the modern world" (Allan 15). The advancements made life easier but in many respects created complex problems such as overpopulation, rapid urbanization, and the necessity for a legal system for social and civil management of the citizens' life.

Charles Dickens's Bleak House is a bitter satirizing critique of the Victorian failure to provide such trustworthy system of social management which manifests itself in various aspects of life in the England of that time.

\section{City: Decayed and Bleak}


London. Michaelmas Term lately over, and the Lord Chancellor sitting in Lincoln's Inn Hall. Implacable November weather. As much mud in the streets, as if the waters had but newly retired from the face of the earth, and it would not be wonderful to meet a Megalosaurus, forty feet long or so, waddling like an elephantine lizard up Holborn Hill. Smoke lowering down from chimney - pots, making a soft black drizzle, with flakes of soot in it as big as full - grown snow flakes - gone into mourning, one might imagine, for the death of the sun. (Dickens 4)

F.S. Schwarzbach in his article "Dickens and the City" asserts that "Dickens, from the time of Oliver Twist, had always felt it a duty to acquaint his reading public with unpleasant but serious social problems, revelations of harsh fact impossible to believe, yet true" (121). This, he fulfilled in Bleak House, but with a distinct feature: The novel does not take into account particular social problems, but instead takes city itself as the major problem to focus at.

This city and its centrality in the author's attention is revealed through the very first lines of the novel, quoted above. Dickens attempts at giving a concrete image of London, and the interesting point is that all the things he points at this passage are the everyday realistic features of this city, such as the weather, animals, fog, smoke, mud, its people and places. However, the overall effect of the combination of these features tinted with the imagination of the author tends to be that of defamiliarization, the enstrangement of familiar objects to intensify the experience. "The individual components are ordinary but they are so colored by the strange atmosphere of the passage that they are transmuted into an alien cosmos" (126).

Fog covers the city, a reminder of the anxieties regarding social and moral degeneracy. Fog was a familiar phenomenon for the populated, industrialized London dwellers, and caught the imagination of many artists and writers who saw in this natural scene a symbol of modernity, passivity, or the impersonality and distance among people. Anna and $\mathrm{T}$. Novakove in an essay entitled "Eyewitness: The Chromatic Effects of Late NineteenthCentury London Fog" quote Oscar Wilde when he talks of the significance of fog in Victorian art and literature:

Where, if not from the Impressionists, do we get those wonderful brown fogs that come creeping down our streets, blurring the gas lamps and changing the houses into monstrous shadows?... At present, people see fogs, not because there are fogs, but because poets and painters have taught them the mysterious loveliness of such effects. (33)

For Dickens, however, the experience was far beyond any loveliness. City is dirty and insubstantial, dissolving into a foggy haze. Fog isolates people from the city around them "as if each were in separate ballons" (Schwarzbach 123).

Darkness shadows the city. The whole London is covered by such a black cloud that one has to put candles on even through the day. Sun is dead and it seems as if city is wearing black in its absence. Mud is every where, a sign of moral blindness. "The mud threatens to dissolve everyone or everything that touches it" (123). Smoke has become a threatening black rain, blocking the sun. The familiar objects are being intensified with amazing new 
connotations to give the final effect of the terrifying atmosphere of darkness and stagnation, intended by the author.

But was London really as horrifying as the picture Dickens gives in this novel? Schwarzbach has attempted to deal with the reality of city life in the London of Dickens's time in his article, taking into account such common objects as mud.

The mud of mid-century London was, after all, quite different from the harmless if messy stuff children today make into pies. It was compounded of loose soil to be sure, but also of a great deal more, including soot and street litter, and the fecal matter of the legion horses on whom all transport in London depended (124).

The interesting point for the modern reader to know is that many sewers were completely open, and in rainy weather would overflow into the streets. In addition, dogs and cattles and even many people used streets as privy, which were simply holes in the ground with drainage into ditches. There was no drainage system and the result of the whole phenomenon was that the mud in the streets of London must have been nothing less than liquid ordure. There were sweepers as Jo, the poor sweeper of the Bleak House, whose job was to clean the path by sweeping the mud, for the well-dressed pedestrians. Jo's identity is defined through his job, for beyond sweeping he is ignored, and this is the same doom for all other mud sweepers like Jo. And this indifference is what Dickens attacks fiercely through the symbolic representation of everyday images and objects of London streets.

In chapter 22, Mr. Sangsby, who is taken out on a tour of Tom-All-Alone's by Inspector Bucket, finds there "such smells and sights that he, who has lived in London all his life, can scarce believe his senses" (408). At the end of the chapter, when going homeward, he is "so confused by the events of the evening that he is doubtful of his being awake and out doubtful of the reality of the streets through which he goes - doubtful of the reality of the moon that shines above him" (409).

This insensitivity is what Dickens felt he must uncover - the insensibility of an audience dissociated from their perceptions of the actual world in which they lived. Fog, smoke, mud and clouds are the realities, closely described, of a society which fails to understand the poors and the miserables, and its aristocrats suffers from ignorance, irresponsibility, indifference and passivity.

\section{The Court of Chancery, Law, Lawyers: Justice or Profit?}

Bleak House is a novel that contains a complicated web of subplots, major characters, and minor characters; however, one main theme carried throughout the novel is the Victorian legal system, specifically the corruption of it. The court that Dickens refers to as the center of major events in novel is the Court of Chancery, one of the two main British courts of the time. Fowler describes that the Court of Chancery was a court of “... equity, or property issues, rather than law and used different principles to arrive at judgments" (2). He elaborates on the history of this judicial court by declaring that it was founded around the medieval period as a branch of the King's Council. The other law court of England called the Court of Common Law was, at this time, seen as insufficient at providing adequate justice for the 
people, so the king established his new court which was supposed to be founded on principles of "conscience, morals, fairness and equality" (2). Unfortunately, by the time Dickens was writing novels, this judiciary system was already plunged into corruption because of "... outrageous delays, inflexible rules, corruption and excessive fees. Hence, ironically, Chancery had become the perpetrator of the judicial abuses it had been established to remedy" (2).

The case taking place through Bleak House is titled Jarndyce and Jarndyce and it is called by Dickens in chapter 1 as a "scarecrow of a suit" which "... has in course of time, become so complicated that no man alive knows what it means" (8). Generations are borne and dead, but "Jarndyce and Jarndyce still drags its dreary length before the court, perennially hopeless" (8).

Although the original purpose of the court of Chancery was to be a court of fairness and equity, the actual proceedings of the court were quite different. In actuality, the excessively lengthy duration of lawsuits and the amount of money it cost made the British judicial system a matter of laugh, as Dickens asserts: "Jarndyce and Jarndyce has passed into a joke. That is the only good that has ever come of it" (7). Dickens's reproach goes beyond this mild humorous satire when he ominously warns "suffer any wrong that can be done you, rather than come here" (6).

Lawyers are central figures in this bulking novel. Three solicitors and a solicitor's clerk play significant roles in Bleak House. Conversation Kenge is solicitor for John Jarndyce, and William Guppy is a clerk in his office. Mr. Vholes represents John's ward, Richard Carstone, in Jarndyce and Jarndyce. Mr. Tulkinghorn is solicitor for Sir Leicester Dedlock. All of these characters are objects of derision in the novel, mostly because of their failure in fulfilling their conduct as lawyers and sometimes for their personal traits.

\subsection{Mr. Tulkinghorn}

Mr. Tulkinghorn is a well-known lawyer $\mathrm{He}$ is the "master of the mysteries of great houses" (8) and he carries family secrets of the aristocrats "in every limb of his body, and every crease of his dress" (16). In Lady Dedlocks' words, "his calling is the acquisition of secrets, and the holding possession of such power as they give him" (18). He is "always at hand. Haunting every place and there is no relief or security from him for a moment" (273). Yes. Mr. Tulkinghorn is knowledgeable and powerful, but in the world of Bleak House "knowledge and power and secrecy is treachery, and Tulkinghorn possesses more knowledge and secrets than anyone" (Mcchrystal 2).

Dickens portraits Tulkinghorn with two different masks. At Chesney Wold, the Dedlock House, he is the trusted advisor and intimate of Sir Leicester Dedlock. In London, Tulkinghorn passes his time wandering through the back alleys and dark places gathering information and documents to prove that the eminent Lady Dedlock hand an affair and gave birth to a child before marrying Sir Leicester. He moves between these two worlds silently, changing the masks skillfully right on time.

The lawyer - client relation is inverted by Turkinghorn's actions. His knowledge of family secrets gives him power over his client, by keeping him in the dark, and over his client's wife, by threatening disclosure "The agent has become the master of his client's fate, and 
Tulkinghorn threatens to use his new power by exposing Lady Deadlock's secret to the whole house, guests and servants included, if she attempts to flee" (Mcchrystal 3). Tulkinghorn brings death directly or indirectly to many: Driven from her home and family, Lady Dedlock dies at the gates of her lover's burial ground. Jo, who supplied information for Tulkinghorn also dies and Mademoiselle Hortense, his other informant who eventually murders him, is likely headed to the gallows. That's right that Tulkinghorn does not hand in any of these deaths directly, but Dickens symbolically shows the readers that Tulkinghorn, the representative of London court, brings misery to many instead of relieving their pains and problem.

\subsection{Mr. Vholes}

A lawyer for Richard Carstone, he always wears black dress and black glove, buttoned to the chin. His digestive problems cause him to eat little, so that in his dark clothes he resembles a "long thin shadow" (190), and his gloves, even when worn, "scarcely seemed to have any hand in it" (191). He is repulsive without speaking a word. He is reproached by both appearance and manner, very opposite to the open, upright and fresh John Jarndyce. Mcchrystal interestingly compares the relation between Richard (the client) and Vholes (the lawyer) to that of "a drug addict and his supplier" (5). Richard was born into Jarndyce and Jarndyce and believes his life must be unsettled until the case is resolved. Up to the end of the story, he is obsessed with the case and devotes his entire life to the resolution of the case. Vholes, however, encourages Richard in this addictive pursuit. Vholes tells Richard that the suit is moving, that progress is being made, that the day is near that he congratulates him on his "accession to fortune" (701). He does so because his benefit is in the case to be prolonged in the court. In fact, he denies Richard to see the reality of the case and in this way results his death. Vholes profits, while his client loses everything, his family, his assets, his life. Like Tulkinghorn's client, Vholes' client dies at the lawyer's hand.

\subsection{William Guppy}

Guppy is characterized by his duplicity and his instability. He asserts his love for Esther, then takes it back, then again asserts it. It is clear that his proposal is not rooted in love but his expectation that Esther will inherit some of the Jarndyce estate. He accompanies Tulkinghorn in following Lady dedlock's secret: "a conspirator without a clear purpose" (Mcchrystal 7). Dickens tells the readers that "he in the most ingenious manner takes infinite pains to counterplot, when there is no plot" (160).

Once the lawyers in Chancery get hold of a case, they expand the dispute rather than resolve it. Dickens suggests that many laws and decisions are issued only for the financial benefit of lawyers. For example, there is a reference to a Parliamentary committee hearing in which a proposed law is rejected even though the current law produces "unjust results, unnecessary delay, and exorbitant expense" (407). The reason for the rejection of the measure is that it would put some lawyers, like the respectable Mr. Vholes, out of business. The successful argument is finally phrased: "Make man-eating unlawful, and you starve the 
Vholese!" (410). Right and wrong, thus for the parliament means, what effect will the purposed law have on lawyers.

\subsection{Perspectivism and the Concept of Legal Right and Wrong}

Dickens, through various examples in the novel, poses the question, "what is the true legitimacy?" (965).

Miss Barbary's belief in this legally-held ideology that illegitimacy and shame are actually one, leads her to cut all ties with her family, to hide the fact that she was Esther's aunt, and to punish the childe for the sins of her parents. K. Dolin quotes Jenny Bourne Taylor to refer to the matter of illegitimacy and shame during Victorian period: "the shame of illegitimacy is internalized to a greater degree, as the illegitimate child is doubly perceived as bearing and being the mother's mark of shame" (20). It is predictable that Esther, when informed of her legal non-identity, describes herself as a "destitute subject" (413). Taylor concludes that "Esther's illegitimacy becomes a means of exploring femininity at the edge of law, with no identity within it, yet no stand point to speak outside it" (qtd. in Dolin 23).

Besides Esther's case, there are other examples in the novel that emphasize the existence of different perspectives through which one can consider one single subject. The best example is Tulkinghorn's pursuit of Lady Dedlock's secret. Is, really, his conduct legal or illegal, wrong or right? On the one hand, Tulkinghorn is the family lawyer of Dedlock family, and therefore one on whom the master of the house has to rely fully. He, as a result, may defend his action by saying that he has implied authority to undertake the investigation given the broad range of responsibilities Sir Leicester entrusted him. On the other hand, one might say that he is a villain in Bleak House because his conduct exceeds his authority and fails to regard the ethics by violating the moral norms. This is how Dickens - the Victorian novelist displays perspectivism in characterization of his central figures. Various perspectives may lead a character like Tulkinghorn, so seemingly villainous in the novel, seems not so bad when measured by other group of standards. Esther with her guilt of the shame of illegitimacy, Lady Dedlock with a faithful memory of a long lasting love, and Tulkinghorn with his mischievous secrecies, all are there to play with the mind of reader: whether he is misunderstood or whether his standards are somehow to blame?

\section{Disease, Hunger, Death: Rotten Bodies, Rotten London}

In his 1880 essay "Fiction, Fair and Foul", John Rulkin talks of "varieties of method" by which characters in Bleak House expire. He concludes that as the result of life in the "smoking mass of decay" that is the city, the "thoroughly trained Londoner" has turned not to "dreams of pastoral felicity" but rather to the putrescence "to which he has accustomed, and asks for that in continually more ardent or more virulent concentration" (158).

Dickens, Ruskin believes, is a master of depicting filth, disease and death and Bleak House serves as Ruskin's case of study:

In the single novel of Bleak House there are nine deaths (or left for death's, in the drops scene) carefully wrought out or led up to [...] with as much 
enjoyment as can be contrived in the anticipation, and as much pathology as can be concentrated in the description. (159)

Aside from Ruskin's study, a survey of the novel shows that characters suffer from gout, stroke, small pox, tuberculosis, Meniere's disease, and even spontaneous combustion arising from the bodily humors. The question here is, why has Dickens made carful descriptions for each disease? Is it possible that disease is intended to move beyond its literal meaning and serve a symbolic interpretation?

Michael S. Gurney in "Disease as Device: The Role of Small pox in Bleak House" declares that "the Victorians, Dickens included, frequently deployed the language of body to talk about system external to the body and, inversely, a vocabulary borrowed from economics to talk about human biology" (80). Diseased bodies in Bleak House are metaphors for the economic and social system and Dickens can realize through them, his goals for achieving social reform through his fiction. Dickens, in his depiction of Jo's impoverished enhances the motif of disease and decayed body. Jo, industrious little crossing-sweeper acts as an agent of circulation, clearing away dirt and excrement from the sidewalks. Yet his body is itself associated with the filth he in reality helps to remove. On a symbolic level, he himself is that which must be swept away or "moved on" (287), to allow for other's safe passage through the city. Charley and Esther both take the disease from Jo, but as they receive proper care they recover from small pox while Jo, with nowhere to go, dies in London, to be just one of many "dying thus around us, every day" (734).

"The notion that all bodies might be equally susceptible to disease led not to a less essentialist rising of class difference, but instead to the equation, via metonymy, of the poor with filth; they were not just living in filth - they were filth" (Gurney 90).

\section{Conclusion}

The very general idea that this article tended to trace through studying various aspects of Bleak House was the relationship between art and reality. The study shows how Dickens tried to express a belief that certain aspects of the real world would become remote to our sensibilities, and that it was the role of art to make us aware of them. Beyond that, it was the function of art and the duty of artist, he believed, to change the situation. What the reader doesn't see around, Dickens told them, were those things around that indicated the fundamental social problems and how little actions that were done to solve them. "Whatever was ugly was being ignored: If important aspects of social reality were ugly, they simply would not be allowed to exist" (Schwarzbach 123).

\section{References}

1) Allan, J. M. (Ed.). (2004). Charles Dickens's Bleak House: A Sourcebook. London \& New York: Routledge.

2) Dickenes, Ch. (1991). (1853). Bleak House. Oxford: Oxford UP.

3) Dolin, K. (2008). Law, Literature and Symbolic Revolution: Bleak House. Australasian Journal of Victorian Study. 12(1). 20-38. 
8 | International Journal of Scientific and Management Research 4(8) 1-8

4) Fowler, R. (2012). A history of Chancery and Its Equity. Tennessee Bar Journal. Retrived at: http://www.tba.org/journal/a-history-of-chancery-and-its

5) Gurney, M.S. (1990). Disease as Device: The Role of Small pox in Bleak House. Literature and Medicine. 9. 79-92.

6) Mcchrystal, M.K. (1999). At the Foot of the Master: What Charles Dickens got Right about What Lawyers Do Wrong. Oregon Law Review. 78(2). 1-19.

7) Novakov, A. Novakov, T. (2006). Eyewitness: The Chromatic Effects of Late Nineteenth - Century London Fog. The Literary London Journal. 4(2). 31-34.

8) Ruskin, J. (2009). Fiction, Fair and Foul. London: Dodo Press.

9) Schwarzbach, F.S. (1979). Đickens and the City”. In Bleak House: Homes for the Homeless. London: The Anthlone. 120-5. 